\title{
CLINOPODIUM ALBANICUM (GRISEB. eX K. MALÝ) MELNIKOV NEW SPECIES FOR THE FLORA OF THE REPUBLIC OF MACEDONIA
}

\author{
Vlado Matevski \\ Macedonian Academy of Sciences and Arts, Skopje, Republic of Macedonia \\ *e-mail: vlado.matevski@yahoo.com
}

\begin{abstract}
During floristical investigation in western parts of the Republic of Macedonia one new species of vascular plants was found which was not previously reported for the country - Clinopodium albanicum (Griseb. ex K. Malý) Melnikov.
\end{abstract}

Key words: flora; Macedonia; distribution; Clinopodium albanicum (Griseb. ex K. Malý) Melnikov

\section{INTRODUCTION}

The latest revision of the genera Satureja L., Clinopodium L., Micromeria Bentham, Calamintha Mill. and Acinos Mill, based on modern molecularphylogenetic studies, have led to many new taxonomic solutions, to new taxonomic and nomenclature combinations [1-9]. An attempt was made to clarify the boundaries between the different genera, as well as to determine the real taxonomic status and position of certain species and lower taxa within these genera. The taxonomic solutions based on the specific morphological characteristics at the level of the genera, sections, subsections or species, especially within the genera Micromeria and Clinopodium, in many cases were not very clear and precisely defined, followed by a very complex synonymy, as well as with the inevitable author subjectivism.

On the one hand, some species, depending on author's taxonomic concept, have often changed their taxonomic and nomenclature status within the different genera [e.g. Calamintha grandiflora (L.) Moench, Satureja grandiflora (L.) Scheele, Clinopodium grandiflorum (L.) Kuntze], while on the other hand, some species described from the some parts of the Balkan Peninsula were neglected, such as Clinopodium albanicum (Griseb. ex K. Malý) Melnikov [Micromeria albanica (K. Malý)
Šilić, Satureja albanica Griseb. ex K. Malý] and they were associated with related species from the other areas (Micromeria serpyllifolia).

Aim of the elaboration is to establish the adequate classification of the species of the genus Clinopodium found between Kichevo and Demir Hisar. As these species was often treated within different taxa (Clinopodium albanicum, Clinopodium dalmaticum subsp. bulgaricum, Clinopodium serpyllifolium) we tried to highlight also development of classification history of this species.

\section{EXPERIMENTAL SECTION}

Floristic researches were carried out in the western parts of the territory of the Republic of Macedonia (Demir Hisar, between the villages of Velmevci and Železnec). Herbarium material is deposed in the Herbarium of the Institute of Biology, Faculty of Natural Sciences and Mathematics in Skopje (MKNH). When determining the herbarium material, appropriate literature was consulted - Prodromus Florae peninsulae Balcanicae, II [10]; Flora Europaea, III [11] and other regional floras [12], as well as some special papers [1-9] and databases Euro+Med Plant Base [13] dealing with taxonomy, nomenclature and chorology of the taxa studied. 


\section{RESULTS AND DISCUSSION}

During the our work on Lamiaceae family for the edition "The Flora of the Republic of Macedonia", special attention was paid to the species Clinopodium albanicum, which was discovered in the southwest parts of the territory of the Republic of Macedonia (between Kichevo and Demir Hisar) as well as his relationship with the species Clinopodium serpyllifolium (Micromeria serpyllifolia) and Micromeria bulgarica.

The western Balkan endemic species Clinopodium albanicum (Micromeria albanica, Satureja albanica) was discovered in the vicinity of Prizren, Kosovo, (sub. Micromeria albanica Griseb., Locus classicus: Resnathal = Rekathal bei Prizren, besonders hfg. auf Kalkfelsen bei d. Ruinen d. Schlosses Demanitze, 1839; by A. Grisebach) [14].

From the chronological overview of the data cited in the botanical literature for the taxonomy, nomenclature and distribution of this species can be found the following:

Hayek [10] considers this species (as Satureja albanica) a synonym of the species Micromeria serpyllifolia (MB) Briq, citing it only for the territory of Albania. But, it should be noted that Hayek's territorial boundaries in Prodromus Florae peninsulae Balcanicae do not correspond with today's state borders of the Balkan Peninsula countries.

Malý [15] points this species under the name Satureja albanica Griseb. ex K. Malý.

Chater \& Guinea [11] in the Flora Europaea edition do not mention the species Satureja albanica Griseb. ex K. Malý [= Micromeria albanica (K. Malý) Šilić] et al. They cite the taxon Micromeria fruticosa (L.) Druce subsp. serpyllifolia (Bieb.) P. H. Davis for Crimea, Southwestern Asia and Southwestern Yugoslavia, so according to this we can lead to the conclusion that the data for Southwestern Yugoslavia actually refers to Micromeria albanica.

Diklić [12] in the Flora of SR Serbia edition accepts the decision that Satureja albanica is a synonym of Micromeria serpyllifolia MB, so cites it for Serbia: Kosovo - Prizrenska Bistrica.

Silić [16] in his monograph dedicated to the genera Satureja L., Clinopodium L., Micromeria Bentham, Calamintha Mill. and Acinos Mill. in the flora of Yugoslavia, the status of the species Satureja albanica Griseb ex K. Malý was actualized and he confirm the indepenadent status of the taxon and proposes the following nomenclature commbination - Micromeria albanica (Griseb. ex K. Malý) Šilić stat. et comb. new. Close to the classical locali- ty $($ Resnathal $=$ Rekathal bei Prizren), this species was confirmed later of the several botanists in the canyon of the Prizren Bistrica (Malý [15], Šilić [16]). In the chapter on distribution of this species, besides Kosovo, it is also cited for Albania (In the valley Crni Drim ad pagum Suhodol pr. Peškopija, 27.VIII.1917, Dr. J. Andrásovszky - Herb., Dr Antal Pénzes, Budapest) (Šilić [16]).

Silic [16] in the same monograh on the territory of the Republic of Macedonia cites the speciec Micromeria bulgarica (Velen.) Vandas, based on the data of Vandas [17, 18], for the presence of this species in the area of Demir Hisar, Usunža river and Krivska river. According to Chater et Guinea [11], Micromeria bulgarica as a subspecies is attached to Micromeria dalmatica subsp. bulgarica (Velen.) Guinea, while Bräuchler et al. [3] think that the real position of this species is in the synonymy of Clinopodium dalmaticum (Benth.) Bräuchler \& Heubl. The same solution is present in Euro+Med Plantbase also (http://ww2.bgbm.org/EuroPlusMed/query.asp).

Greuter et al. [19] in the Med-Checklist accept the old nomenclature solution - Satureja albanica K. Malý, so this species is referring to Yugoslavia (Kosovo) and Albania. In the synonymy of this species they include the previous taxonomical and nomenclature solutions for "Micromeria serpyllifolia" (sensu Hayek [10], Diklić [12]) and Micromeria albanica (K. Malý) Šilić. Greuter et al. [19], make a distinction between the species Satureja albanica (Micromeria albanica) and Micromeria serpyllifolia, both in terms of their particular taxonomic status and their distribution. Thus, according to Greuter et al. [19] the area of distribution of the species Satureja serpyllifolia covers the territory of Crimea, the Asian part of Turkey, Lebanon, Syria, Israel and Jordan, while the area of Satureja albanica K. Malý [= Micromeria albanica (K. Malý) Šilić] is located in the western parts of the Balkan Peninsula.

In the Euro + Med Plantbase [13] the old nomenclature combination is returned - Micromeria albanica (K. Malý) Šilić.

Bräuchler et al. [3] in the updated monograph on the genus Micromeria, they disputed the taxonomic value of Micromeria albanica (Satureja albanica) and this species is listed in the synonymy of the species Clinopodium serpyllifolium (M. Bieb.) Kuntze.

Finally, Melnikov [7] actualize again the taxonomic status of the species Micromeria albanica (Satureja albanica) and offers the following combination - Clinopodium albanicum (Griseb. ex K. Malý) Melnikov, comb. new. [Satureja albanica 
Griseb. ex K. Malý $\equiv$ Micromeria albanica (K. Malý) Šilić].

Of all the above, the question is whether the taxonomic status of the Clinopodium albanicum (Griseb. ex K. Malý) Melnikov (Satureja albanica, Micromeria albanica) is justified, or it is a synonym of Clinopodium serpyllifolium (M. Bieb.) Kuntze.

In clarifying this problem, we had extensive literature on these two species as well as a rich herbarium material from the Clinopodium albanicum, collected from the territory of the Republic of Macedonia, in the area of Demir Hisar (between the villages of Železnec and Velmevci). In this respect, the monograph of Šilić [16], which provides an extensive diagnostic description of the species Micromeria albanica (based on the herbarium material from the canyon of the Bistrica river above Prizren), is particularly significant, with detailed morphological characteristics, ecology, inventory of the accompanying plant species registered on his habitat, drawings of the inflorescence, calyx, corolla, bracts, leaves, a photograph of the habitat of this species from its Locus classicus as well as its synonymy.

The analysis of the herbarium material from the area of Demir Hisar showed that the registered populations can not be linked to the species Micromeria bulgarica (Velen.) Vandas (according to modern concepts Clinopodium dalmaticum or Clinopodium dalmaticum subsp. bulgaricum), cited by Šilić [16], for the territory of the Republic of Macedonia (Demir Hisar, Usunja river and Krivska river) based on the data of Vandas [17, 18]. Namely, it should be noted that Šilić [16], in the absence of authentic herbarium material of Micromeria bulgarica from the territory of Macedonia, uses drawings of the most important morphological characteristics of this taxon using herbarium material from the territory of Bulgaria (Rodopi). There is a noticeable difference between these two taxa in the shape and the hairy of the leaves, as well as the size of the calyx and shape of the calyx-teeth. In the herbarium material of Clinopodium albanicum, originating from the territory of the Republic of Macedonia (calyx is regular, 2-2.5 mm long, the calyx-teeth are triangular, about as long as wide)(Figures 1, 3, 4) while in the Micromeria bulgarica (i.e. Clinopodium dalmaticum) originating from the territory of Bulgaria (calyx is longer than 3 $\mathrm{mm}$, the calyx-teeth are elongated, lanceolate to subulate, much longer than wide, acute) (Figure 2).

As for the species Clinopodium serpyllifolium, with whom Clinopodium albanicum (= Micromeria albanica, Satureja albanica) was often linked, its range extends to the territory of Crimea, the Asian part of Turkey, Lebanon, Syria, Israel and Jordan, so the presence of this species on the territory of the Balkan Peninsula is excluded [19].

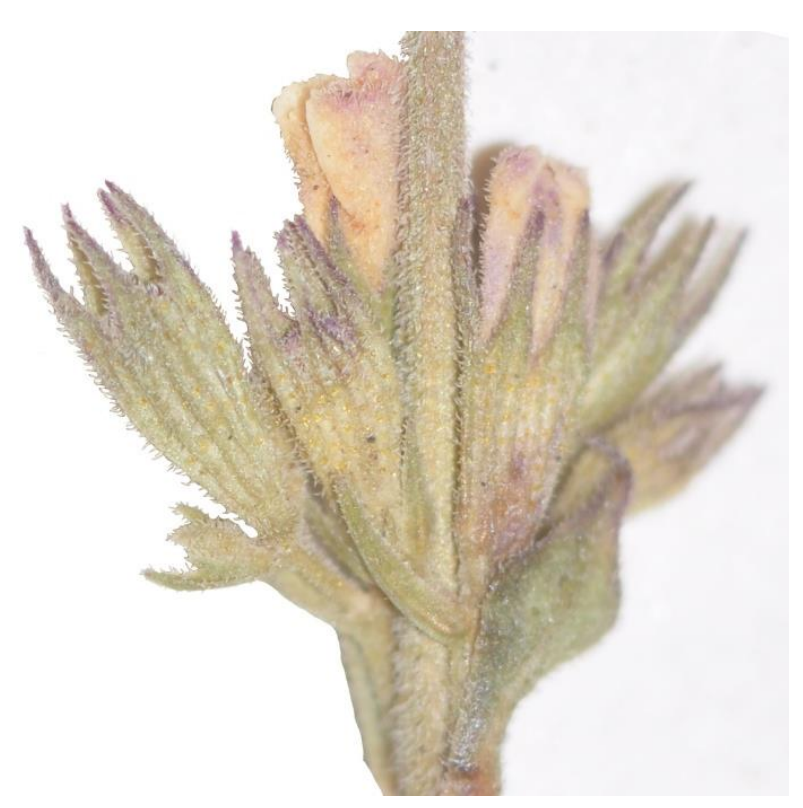

Figure 1. Clinopodium albanicum - calyx (MK: Demir Hisar:Železnec-Velmevci)

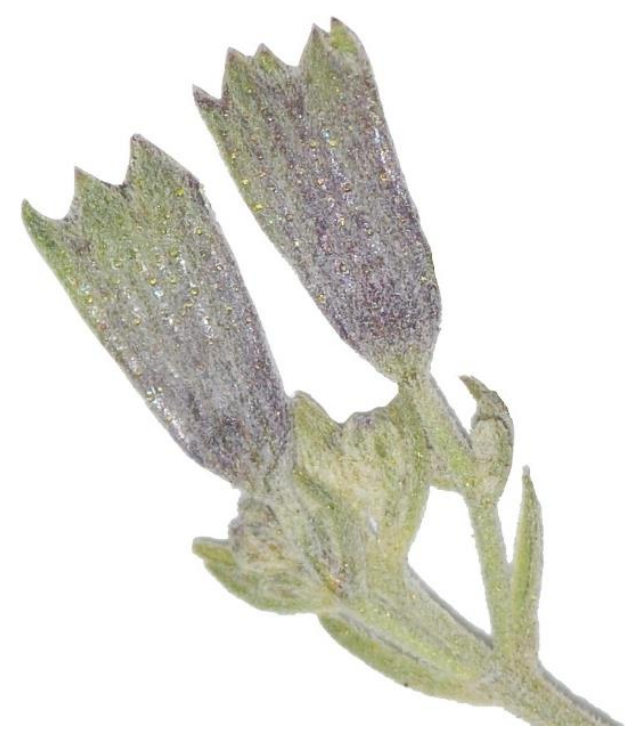

Figure 2. Clinopodium dalmaticum subsp. bulgaricum - calyx (BG: Rodopi)

Melnikov [7] published a very important study devoted to the new sections of the genus Clinopodium, so that within the boundaries of this genus he described several new sections and subsections, which at the same time represent a solid basis for the solution of taxonomic and nomenclature problems at the supraspecies and spe- 
cies level. Namely, Melnikov [7] distinguishes two separate sections that include the above-mentioned closely related species, which are however clearly morphologically and horologically differentiated. In the newly published Sect. Pseudomelissa (Benth.) Melnikov, whose representatives are characterized by a more or less irregular calyx with elongated calyx-teeth, he includes the species Clinopodium dalmaticum (Micromeria bulgarica is usually attached to this species as a subspecies or synonyms). Melnikov [7], in the newly described Sect.
Brachyodontia Melnikov, which differs from the Sect. Pseudomelissa with the almost regular calyx and equal triangular or wide-triangular calyx-teeth, about as long as wide, with short soft hairs on the stems, leaves, calyx and pedicels, separates two subsections - subsect. Brachyodontia and subsect. Inkermenia Melnikov. In subsect. Brachyodontia, stem hairs are retrorse (here the Clinopodium albanicum species is attached), while in the Subsect. Inkermenia stem hairs are directed upwards (includes the Crimean species $C$. serpyllifolium).

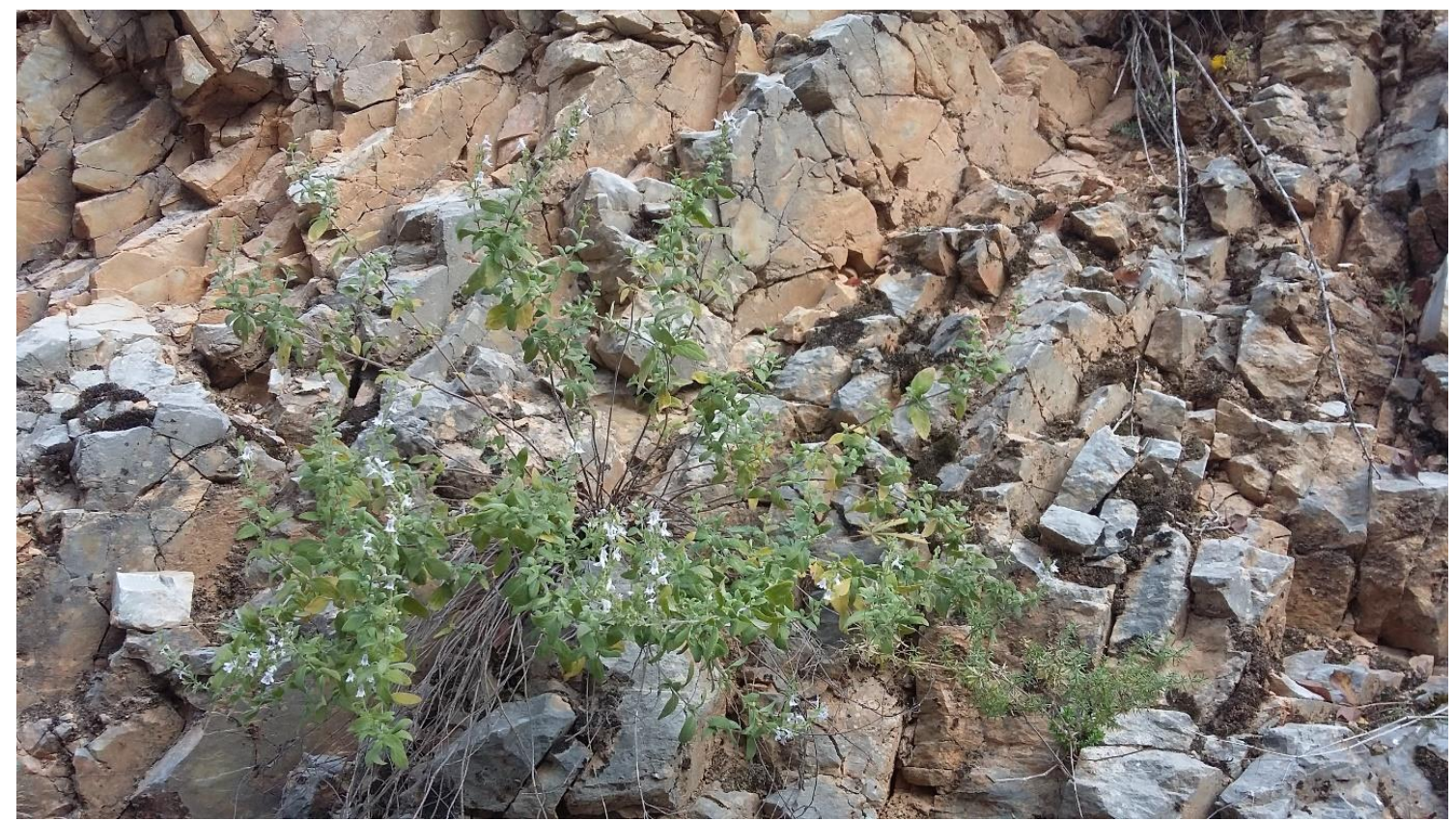

Figure 3. Clinopodium albanicum - habitat of the species (MK: Demir Hisar:Železnec-Velmevci)

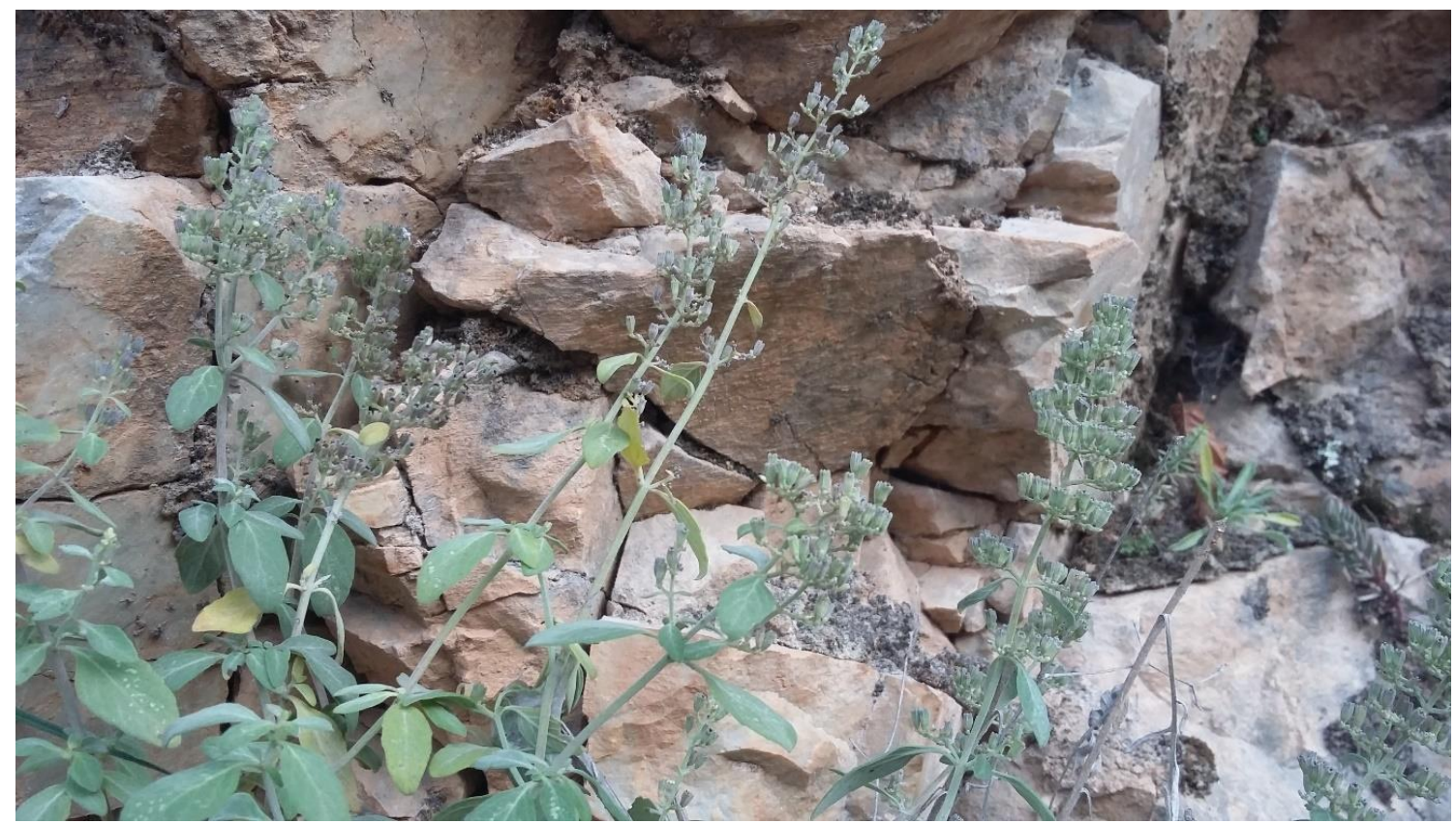

Figure 4. Clinopodium albanicum - habitus of the species (MK: Demir Hisar:Železnec-Velmevci 
From the above, it could be concluded that the taxonomic status of the species Clinopodium albanicum is not questionable. The discovered populations from the area of Demir Hisar (between the villages Velmevci and Zeleznec) (Figure 5) no doubt belong to this species. In this way, the data of Vandas [17, 18] and Šilić [16] for the presence of the Micromeria bulgarica (Velen.) Vandas (Clinopodium dalmaticum or Clinopodium dalmaticum subsp. bulgaricum) in the listed localities on the territory of the Republic of Macedonia are revised.

In addition, we provide a diagnostic description of the population of the Clinopodium albanicum from the following locality: Republic of Macedonia: Demir Hisar: between the villages Velmevci and Zeleznec, along the road KičevoDemir Hisar, on limestone, $41^{\circ} 21^{\prime} 06.14$ "N; $21^{\circ} 02$ '29.80 "E, $853 \mathrm{~m}$; 10/22/2017 (leg. et det. V. Matevski (MKNH).

Perennial plant. Stems up to $40-50 \mathrm{~cm}$, erect or ascending from the base, in the upper part branched, obtuse 4-angled, with very dense, short deflexed hairs, often with a glandular hairs. Leaves ovate to ovate-elongated, (10) 13-25 (38) mm long, (5) 7-10 (17) $\mathrm{mm}$ wide, obtuse, gradually cuneate at base, petiole 4-9 $\mathrm{mm}$ long, entire or shallow dentate with 1-4 teeth on each side, with 3-4 lateral veins, both sides with short puberulent hairs, short stalked glands and glandular-punctate. Flowers shortly pedicellate, cymes many-flowered grouped in terminal inflorescences that are initially compressed, later are fragmented and branched. Bracts linear-subulate. Calyx (2) 2.2-2.8 mm long, obconical with 13 clearly distinctive veins, along the veins of the calyx there are simple retrorse hairs, between the veins with the short stalked glands and glandular-punctate, densely villosus in throat, calyx teeth $0.3-0.7 \mathrm{~mm}$ long, triangular, about as long as wide. Corolla 6-6.5 mm long, whitish or whitish-violet, outside hairy, 2-lipped, the upper lip entire or shallow bifid, lower lip 3-lobed. Stamens and style excerted out corolla. Nutles obtuse, 1.1-1.2 mm long, yellowish-brown.

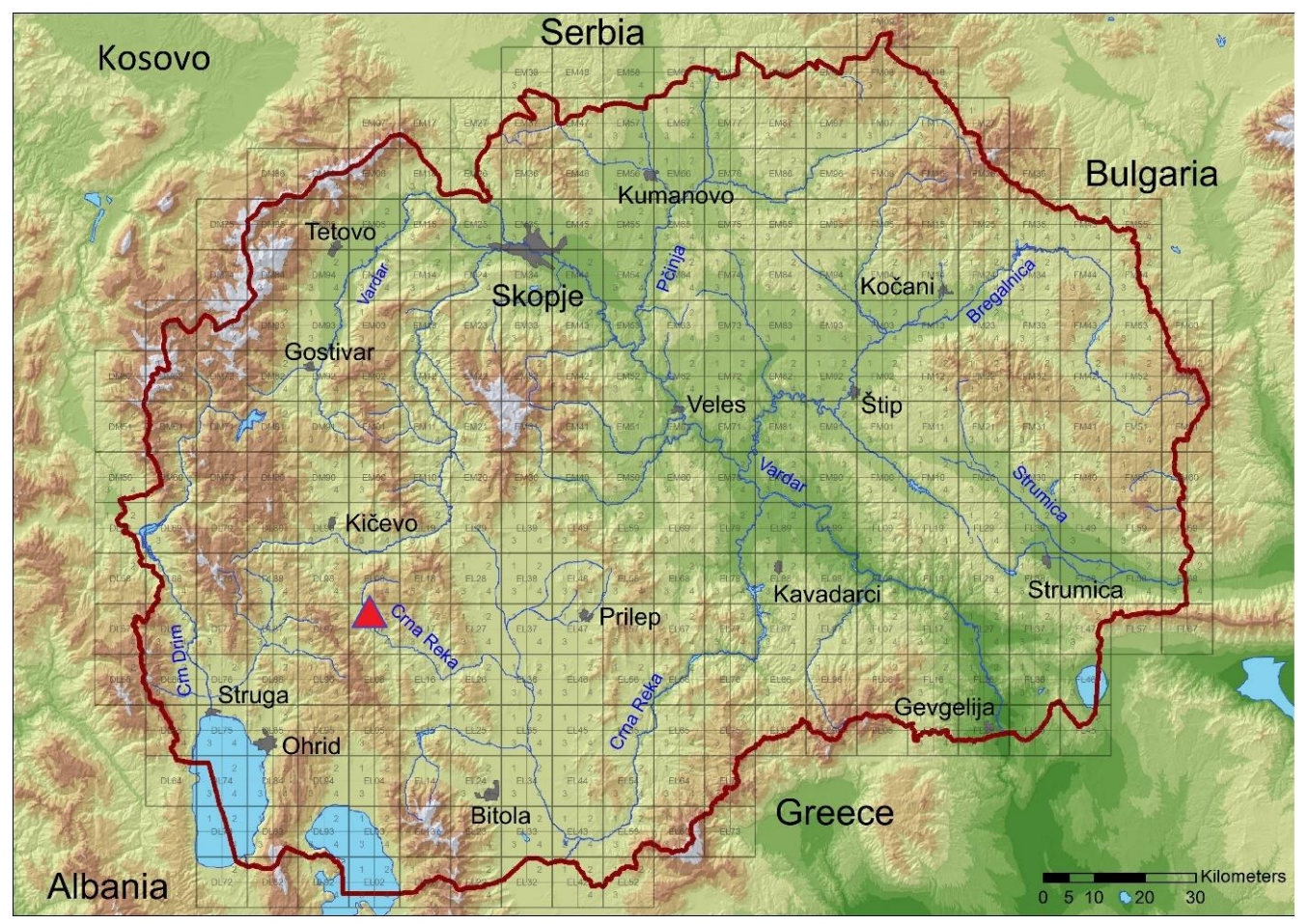

Figure 5. Clinopodium albanicum - Map of distribution in the Republic of Macedonia

\section{REFERENCES}

Acknowledgement. The investigation was supported by the project fund of Macedonian Academy of Sciences and Arts. I thank to Prof. Dr. Slavčo Hristovski for assistance in the preparation of some of the photographs in the paper.
[1] R. Morales, Sinopsis y distribución del género $M i$ cromeria Bentham, Bot. Complutensis, 18 (1993), pp. 157-168.

[2] C. Bräuchler, H. Meimberg, T. Abele, G. Heubl, Polyphyly of the genus Micromeria (Lamiaceae): 
Evidence from cpDNA sequence data, Taxon, 54(3) (2005), pp. 639-650. DOI: 10.2307/25065421

[3] C. Bräuchler, H. Meimberg, G. Heubl, New names in Old World Clinopodium - the transfer of the species of Micromeria sect. Pseudomelissa to Clinopodium, Taxon, 55(4) (2006), pp. 977-981. DOI: $10.2307 / 25065692$

[4] C. Bräuchler, O. Ryding, G. Heubl, The genus Micromeria (Lamiaceae), a synoptical update, Willdenowia 38 (2008), pp. 363-410. ISSN 0511-9618; (C) 2008 BGBM Berlin-Dahlem.

DOI:10.3372/wi.38.38202 (available via http://dx. doi.org/)

[5] T. Arabaci, T. Dirmenci, F. Celep, Morphological character analysis in Turkish Micromeria Bent. (Lamiaceae) species with a numerical taxonomic study, Turk. J. Bot., 34 (2010), pp. 379-389.

[6] E. Martin, O. Cetin, T. Dirmenci, H. Ay, Karyological studies of Clinopodium L. (Sect. Pseudomelissa) and Micromeria Benth. s. str. (Lamiaceae) from Turkey, Caryologia, 64(1) (2011), pp. 398-404. DOI: 10.1080/00087114.2011.10589807

[7] D. G. Melnikov, New sections of the genus Clinopodium L. (Lamiaceae) and their synopsis, Turczaninowia, 18 (3) (2015), pp. 103-112.

[8] D. G. Melnikov, New taxa in the genus Clinopodium L. (Lamiaceae), 2. Turczaninowia 19 (2) (2016), pp. 86-98. DOI: 10.14258/turczaninowia.19.2.12.

[9] D. G. Melnikov, Sistematika i geografia roda Clinopodium L. (Lamiaceae) Evrazii. Doct. thesis 2017 p. 221. Botan. Inst. V. L. Komarov, Rus. Akad. Nauk., Sankt-Peterburg.
[10] A. Hayek, Prodromus Florae peninsulae Balcanicae, II. Feddes Repert., Beih., 30. (1928-1931), Dahlem bei Berlin.

[11] A. O. Chater et E. Guinea, Micromeria Bentham in T. G. Tutin et al. (eds.), Flora Europaea 3, 1972, pp. 167-170, Cambridge.

[12] N. Diklić, Micromeria Bentham in Josifović et al., (eds.) Flora SR Srbije, 6, 1974, pp. 458-462, Belgrade.

[13] Euro + Med Plantbase (http://ww2.bgbm.org/EuroPlusMed/query.asp.).

[14] A. Grisebach, Reise durch Rumelien und nach Brussa im Jahre 1839, II Band, 1841, p. 320. Göttingen.

[15] K. Maly, Satureja-Arten Südserbiens. Bull. Inst. Jard. Botan. Univer. Belgrade, 1(3) (1930), pp. 229-232, Belgrade.

[16] Č. Šilić, Monografija rodova Satureja L., Calamintha Miller, Micromeria Bentham, Acinos Miller i Clinopodium L. u flori Jugoslavije. Zemaj. Muzej BiH, Posebno izdanje, Sarajevo, 1979, 440 p.

[17] C. Vandas, Novae Plantae Balcanicae. Mag. Bot. Lapok, 4 (1905) pp. 109-113.

[18] C. Vandas, Reliquiae Formánekianae, Enumeratio critica plantarum vascularium quas itineribus in haemo peninsula et Asia minore (Bithynia) factis collegit Dr Ed. Formanek, professor gymnasia Brunensis Bohemici, 1909, p. 612, Brunae.

[19] W. Greuter, H. M. Burdet, G. Long, Med-Checklist, Dicotyledones (Convolvulaceae-Labiatae), 3 (1986), p. 395, Geneve-Berlin-Dahlem.

\section{CLINOPODIUM ALBANICUM (GRISEB. EX K. MALÝ) MELNIKOV НОВ ВИД ЗА ФЛОРАТА НА РЕПУБЛИКА МАКЕДОНИЈА}

\section{Владо Матевски}

\section{Македонска академија на науките и уметностите, Скопје, Република Македонија}

Во текот на флористичките истражувања во западните делови од територијата на Република Македонија (во околината на Демир Хисар, помеѓу селата Велмевци и Железнец) е откриен еден нов вид за флората на Република Македонија - Clinopodium albanicum (Griseb. ex K. Malý) Melnikov [Micromeria albanica (K. Malý) Silic, Satureja albanica Griseb. ех K. Malý], досега непознат за нејзината територија. Во трудот се разгледува проблемот околу оправданоста на таксономскиот статус на овој вид и неговата поврзаност со таксоните Clinopodium dalmaticum (односно Clinopodium dalmaticum subsp. bulgaricum = Micromeria bulgarica и Clinopodium serpyllifolium).

Анализата на хербариумскиот материјал од околината на Демир Хисар покажа дека регистрираните популации не можат да се поврзат со видот Micromeria bulgarica (Velen.) Vandas (според современите концепти Clinopodium dalmaticum или Clinopodium dalmaticum subsp. bulgaricum), кого Šilić (1979), го наведува за територијата на Република Македонија - Демир Хисар, Усунжа Река и Кривска Река (врз основа на податоците на Vandas, 1905, 1909). Забележлива е големата разлика помеѓу овие два таксони во обликот и влакнетоста на листовите, како и во големината на чашката и обликот на запците на чашката. Кај Clinopodium albanicum од територијата на Република Македонија чашката е правилна, 2-2,5 мм долга, запците на чашката се триаглести, со еднаква должина и ширина додека кај Micromeria bulgarica (односно Clinopodium dalmaticum) од територијата на Бугарија чашката повеќе или помалку е двоусна, подолга од 3 мм, чашкините запци се издолжено триаглести и тие се со долг зашилен врв.

Клучни зборови: флора; Република Македонија; хорологија; Clinopodium albanicum (Griseb. ex K. Malý) Melnikov 